Volume 4 Nomor 2, Juli-Desember 2020: hlm. 95-110.

Fakultas Hukum, Universitas Lampung,

Bandar Lampung, Lampung, Indonesia.

E-ISSN: 2598-3105 P-ISSN: 2723-2581

http://jurnal.fh.unila.ac.id/index.php/cepalo

\title{
ANOMALI KEHADIRAN PEGAWAI PEMERINTAH DENGAN \\ PERJANJIAN KERJA (PPPK) DALAM CAKRAWALA \\ KEPEGAWAIAN DI INDONESIA
}

\section{THE ANOMALY OF THE PRESENCE OF GOVERNMENT EMPLOYEES WITH THE EMPLOYMENT AGREEMENT (PPPK) IN THE EMPLOYMENT HORIZON IN INDONESIA}

\section{Legina Nadhila Qomarani}

Program Magister Ilmu Hukum, Fakultas Hukum Universitas Indonesia, Email: Leginadhilah@gmail.com

Submitted: June 12, 2020; Reviewed: June 30, 2020; Accepted: July 9, 2020

DOI: $10.25041 /$ cepalo.v4no2.1979

\begin{abstract}
Abstrak
Perjalanan panjang birokrasi yang penuh rintangan dan berbagai kelemahan sejatinya sangat menuai banyak kritikan sehingga menjadi sebuah tantangan besar bagi birokrasi untuk melakukan upaya mereformasinya. Salah satu upaya mendasar yang perlu disasar dalam reformasi birokrasi adalah penataan sistem manajemen SDM Aparatur Negara dalam peraturan perundang-undangan. Hadirmya Undang-Undang Aparatur Sipil Negara yang secara sekuensial menghadirkan PPPK dalam cakrawala kepegawaian di Indonesia merupakan langkah Pemerintah dalam upaya mereformasi birokrasi. Pasalnya, kehadiran PPPK yang secara mutatis mutandis menghapuskan eksistensi tenaga honorer disinyalir mampu untuk lebih memberikan perlindungan hukum dan menjawab carut marut perihal kompetensi, integritas dan profesionalitas Aparatur Negara. Tulisan ini secara khusus bertujuan untuk mendiskursuskan kehadiran PPPK dalam cakrawala kepegawaian di Indonesia sebagai suatu anomali dengan menguraikan berbagai problematika yang lahir seiring dengan lahirnya PPPK dan bagaimanakah eksistensi PPPK ke depannya dalam persinggungannya dengan Tenaga Ahli. Diskursus tulisan ini adalah penelitian hukum normatif dengan tipologi penelitian yang bersifat preskriptif-analitis dengan menggunakan pendekatan perundang-undangan (statute approach). Dengan melakukan analisis terhadap berbagai peraturan perundang-undangan yang meliputinya, hasil dari penelitian ini memperlihatkan bahwa dalam persinggungannya dengan eksistensi Tenaga Ahli, jika berbagai problematika seputar PPPK tidak segera diatasi, maka seiring berjalannya waktu eksistensi PPPK hanya akan tenggelam ditelan permasalahan. Dalam hal ini, Pemerintah (Presiden) sebagai pembentuk undang-undang dan para pemangku kepentingan (stakeholders) lainnya agar segera menetapkan peraturan pelaksana yang lebih khusus dan terperinci dalam upaya memaksimalkan perekrutan PPPK yang diharapkan dapat dilaksanakan secara profesional, transparan dan objektif, serta bebas dari intervensi politik dan bersih dari KKN. Hal demikian tentu saja dapat dinilai mampu memberikan keadilan dan kepastian hukum bagi PPPK dan tenaga honorer/pegawai tidak tetap lainnya yang selama ini telah ada dan diakui.
\end{abstract}


Kata Kunci: Ahli, Manajemen, PPPK, Tenaga.

\section{Abstract}

The long journey of bureaucracy which is full of obstacles and various weaknesses actually has drawn a lot of criticism so that it becomes a big challenge for the bureaucracy to make efforts to reform it. One of the fundamental efforts that need to be targeted in bureaucratic reform is the management system of human resources of the State Apparatus in legislation. The presence of Civil State Apparatus Law which sequentially presents PPPK in the employment horizon in Indonesia is actually a step of the Government in efforts to reform the bureaucracy. The presence of PPPK, which eliminates the existence of honorary staff, allegedly being able to provide more legal protection and respond to chaos regarding the competence, integrity and professionalism of the State Apparatus. This article specifically aims to discuss the presence of PPPK in the employment horizon in Indonesia as an anomaly by describing the various problems that arise along with the presence of PPPK and how the future of PPPK will be in contact with Experts. The discourse of this article is normative legal research with a prescriptive-analytical research typology using a statutory approach. By analyzing the various laws and regulations that cover it, the results of this paper show that in contact with the existence of Experts, if various problems surrounding PPPK are not immediately resolved, then over the time the existence of PPPK in the future will disappear and sink in the swallow of problems. In this case, the Government (the President) as the legislators and other stakeholders should immediately establish more specific and detailed implementing regulations in an effort to maximize PPPK recruitment which is expected to be carried out professionally, transparently and objectively, free from political intervention and clean from KKN. Of course, this can be considered capable of providing justice and legal certainty for PPPK and other honorary / non-permanent employees who have been there and recognized so far.

Keywords: Experts, Management, PPPK, Staff.

\section{A. Pendahuluan}

Perjalanan panjang birokrasi yang penuh rintangan dengan berbagai kelemahan hingga kini sangat menuai banyak kritikan. Hal ini sejatinya merupakan tantangan birokrasi sehingga diskursus perihal jalan keluarnya adalah sesuatu yang selalu menarik diperbincangkan. Tidak dapat dipungkiri bahwa citra negatif dan kinerja buruk birokrasi sangat mempengaruhi berbagai aspek di dalam pembangunan dan membuat kepercayaan masyarakat terhadap birokrasi menjadi rendah. Pada titik inilah perbaikan dan pembenahan dalam upaya mereformasi birokrasi menjadi langkah strategis yang harus diambil oleh Pemerintah selaku pemegang otoritas tertinggi sebagai bentuk tanggung jawab untuk mengembalikan hilangnya kepercayaan publik (distrust). ${ }^{1}$ Salah satu perubahan mendasar yang perlu disasar dalam reformasi birokrasi adalah manajemen SDM Aparatur Negara sebagai penopang eksistensi birokrasi yang hingga kini masih diselimuti berbagai problematika, misalnya dalam hal rendahnya kompetensi Aparatur Negara yang secara sekuensial berdampak pada rendahnya kinerja birokrasi secara umum. ${ }^{2}$ Penataan sistem manajemen SDM Aparatur Negara dalam

\footnotetext{
1 Rike Anggun Artisa, "PEGAWAI PEMERINTAH DENGAN PERJANJIAN KERJA (PPPK): $R E V I E W$ TERHADAP UNDANG-UNDANG NOMOR 5 TAHUN 2014 TENTANG APARATUR SIPIL NEGARA", Jurnal Pembangunan dan Kebijakan Publik 6, no. 1, (2015): 33-42, 33.

${ }^{2}$ Ibid., 34.
} 
peraturan perundang-undangan menjadi conditio sine qua non dalam upaya mereformasi birokrasi dan dalam rangka meningkatkan kompetensi dan profesionalitas Aparatur Negara. ${ }^{3}$ Hal ini dapat dilihat dari upaya sungguh-sungguh Pemerintah dalam merumuskannya ke dalam peraturan perundang-undangan yang hingga kini terus dilakukan upaya penyempurnaan.

Upaya penyempurnaan tersebut ditandai dengan dilakukannya beberapa kali perubahan terhadap peraturan perundang-undangan yang mengatur perihal Aparatur Negara. Setelah Undang-Undang Nomor 8 Tahun 1974 tentang Pokok-Pokok Kepegawaian diubah dengan Undang-Undang Nomor 43 Tahun 1999, dewasa ini, lahirlah Undang-Undang Nomor 5 Tahun 2014 tentang Aparatur Sipil Negara yang substansinya mengubah paradigma pengaturan kepegawaian dan mendikotomi Pegawai ASN menjadi PNS dan PPPK. Selain itu, paradigma yang dikedepankan dalam UU ASN adalah pemberlakuan merit system sebagai antitesis dari spoils system untuk mewujudkan birokrasi yang profesional dan menghindari adanya politisasi dalam tubuh birokrasi. ${ }^{4}$ Reformasi kepegawaian merupakan salah satu kegiatan penting dari keseluruhan rangkaian kegiatan reformasi birokrasi suatu pemerintahan. ${ }^{5}$

Kehadiran PPPK dalam cakrawala kepegawaian di Indonesia secara mutatis mutandis menghapuskan eksistensi pegawai tidak tetap atau tenaga honorer yang sebelumnya dikenal dalam peraturan perundang-undangan perihal Aparatur Negara. Kehadiran PPPK disinyalir bertujuan untuk lebih memberikan perlindungan hukum terhadap tenaga honorer atau pegawai tidak tetap dan menjamin adanya integritas dan profesionalitas dalam tubuh kepegawaian di Indonesia, yaitu dengan rekrutmen yang bebas dari Korupsi, Kolusi, dan Nepotisme (KKN) guna mewujudkan reformasi birokrasi. ${ }^{6}$ Selaras dengan hal tersebut, Prasojo menegaskan bahwa rekrutmen PPPK bertujuan untuk memperkuat basis kompetensi dan profesionalitas dalam penyelenggaraan birokrasi. Dalam narasi yang lebih positif, hadirnya PPPK diharapkan dapat memberikan percepatan atau akselerasi dalam meningkatkan kompetensi dan menciptakan profesionalitas Pegawai Aparatur Sipil Negara. ${ }^{7}$

Berlandaskan hal-hal tersebut, rumusan masalah dalam diskursus tulisan ini yaitu Pertama, apakah yang menjadi ratio legis dari lahirnya UU ASN yang secara sekuensial menghadirkan PPPK dalam cakrawala kepegawaian di Indonesia. Kedua, problematika apa sajakah yang lahir seiring dengan lahirnya PPPK dan bagaimanakah eksistensi PPPK ke depannya dalam persinggungannya dengan Tenaga Ahli. Diskursus tulisan ini adalah penelitian hukum normatif dengan tipologi penelitian yang bersifat preskriptif-analitis yang menguraikan berbagai permasalahan seputar PPPK dan menawarkan solusi penyelesaiannya. Penelitian hukum ini menggunakan pendekatan perundang-undangan (statute approach) dengan menelaah berbagai regulasi dan peraturan perundang-undangan yang bertalian dengan kepegawaian. Adapun jenis data yang digunakan adalah data sekunder yang kemudian dapat dibedakan ke dalam bahan hukum primer yang meliputi Undang-Undang Aparatur Sipil Negara dan peraturan pelaksananya yaitu Peraturan Pemerintah Nomor 49 Tahun 2018

\footnotetext{
${ }^{3}$ Ahmad Ghufron, et al., Hukum Kepegawaian di Indonesia, Cetakan Pertama, (Jakarta: Rineka Cipta, 1991), 1.

${ }^{4}$ Leni Lohida, "ANALISIS KOMPARASI PEGAWAI PEMERINTAH DENGAN PERJANJIAN KERJA (PPPK) DALAM PARADIGMA UNDANG-UNDANG NOMOR 5 TAHUN 2014 TENTANG APARATUR SIPIL NEGARA", Jurnal Civil Service 9, no. 2 (2015): 45-53, 47.

5 Joko Tri Haryanto, "ANALISIS BEBAN FISKAL MANAJEMEN PEGAWAIA PEMERINTAH DENGAN PERJANJIAN KERJA", Jurnal Civil Service 9, no.2, (2015): 31-44, 32.

6 Nurmalita Ayuningtyas Harahap, "PERLINDUNGAN HUKUM PEGAWAI PEMERINTAH DENGAN PERJANJIAN KERJA UNTUK MEWUJUDKAN REFORMASI BIROKRASI", Jurnal Hukum Justitia Et Pax 32, no. 2, (2016): 13-31, 14, DOI: 10.24002/jep.v32i2.1144.

${ }^{7}$ Eko Prasojo, "JANGAN SAMPAI PPPK DIJADIKAN ALAT PENDULANG SUARA PEMILU". Dalam Agustinus Sulistyo Tri Putranto, "PEGAWAI PEMERINTAH DENGAN PERJANJIAN KERJA: PENGERTIAN DAN URGENSINYA", Jurnal Kebijakan dan Manajemen PNS 9, no. 2, (2015): 1-10, 2.
} 
tentang Manajemen PPPK serta bahan hukum sekunder yang diperoleh dari berbagai buku teks dan jurnal-jurnal ilmiah. Adapun metode analisis data yang digunakan adalah kualitatif berdasarkan kemampuan penalaran penulis dalam menganalisis isu hukum yang sedang dihadapi.

\section{B. Pembahasan}

\section{Kehadiran PPPK dalam Cakrawala Kepegawaian di Indonesia}

Lahirnya suatu undang-undang tentu saja disertai dengan landasan filosofis dan dasar ontologis yang menjadi fondasi tegak dan berdirinya suatu undang-undang. Merujuk pada ratio legis lahirnya UU ASN, hadirnya PPPK yang menjadi bagian dari Pegawai ASN sejatinya merupakan bagian dari agenda reformasi birokrasi yang disinyalir mampu mengakomodir SDM yang unggul dan profesional. $^{8}$ Dalam narasi yang lebih optimis, hadirnya PPPK dalam cakrawala kepegawaian di Indonesia bukanlah "main-main", dari mulai penetapan kebutuhan, pengadaan, penilaian kinerja, hak dan kewajiban, gaji dan tunjangan, pengembangan kompetensi, pemberian penghargaan, disiplin, pemutusan hubungan kerja, hingga berbagai perlindungan akan diberikan kepada PPPK dan terangkum dalam sebuah manajemen PPPK.

Kata kunci yang mendasari pertimbangan lahirnya PPPK dalam UU ASN adalah ASN itu sendiri sebagai profesi yang memiliki kewajiban untuk mengelola dan mengembangkan diri serta mempertanggung jawabkan segala kinerja. Selain itu juga penerapan merit system dalam implementasi manajemen ASN yang tentu saja mensyaratkan adanya keahlian dan kemampuan khusus dalam bekerja. ${ }^{9}$ Dengan demikian, dapat dikatakan bahwa pekerjaan yang bersifat profesional tentu saja merupakan pekerjaan yang hanya dapat dilaksanakan oleh orang-orang khusus yang kompeten dan benar-benar dipersiapkan untuk menjalankan pekerjaan tersebut.

Jika mengikuti logika berfikir UU ASN, maka sejatinya kehadiran PPPK dalam cakrawala kepegawaian di Indonesia benar-benar dipersiapkan bagi orang-orang terpilih. Ada kekhususan, keistimewaan, dan pengutamaan yang mengindikasikan bahwa PPPK bukan hanya sebagai wadah yang akan diisi secara otomatis oleh para pegawai tidak tetap atau pegawai honorer sebelumnya melainkan tetap harus memenuhi persyaratan dan mengikuti serangkaian proses seleksi dan mekanisme rekrutmen yang telah ditentukan dalam UU ASN dan peraturan pelaksananya yaitu Peraturan Pemerintah Nomor 49 Tahun 2018 tentang Manajemen PPPK sebagai penterjemahan dari pada merit system.

Kendati demikian, hadirnya PPPK dalam cakrawala kepegawaian di Indonesia tidak bisa dilepaskan dari berbagai problematika yang menyelimuti kehadirannya. Problematika tersebut lahir seiring dengan kelahiran PPPK yang diinisiasi oleh lahirnya UU ASN pada tahun 2014 yang menghapuskan eksistensi pegawai tidak tetap/tenaga honorer dari cakrawala kepegawaian di Indonesia. Lahirnya UU ASN yang tidak diiringi dengan lahirnya peraturan pelaksana sebagai pengimplementasian dari lahirnya gagasan PPPK tentu saja hanya melahirkan problematika baru. Sebagaimana kita ketahui, PP Manajemen PPPK baru lahir pada tahun 2018, itu artinya dalam kurun waktu kurang lebih selama 4 (empat) tahun sejak kelahiran UU ASN pada tahun 2014, gagasan PPPK hanyalah sebuah gagasan belaka tanpa implementasi.

Bertalian dengan hal tersebut, di satu sisi dengan lahirnya UU ASN mau tidak mau eksistensi pegawai tidak tetap atau tenaga honorer harus dihapus karena sudah tidak dikenal

\footnotetext{
${ }^{8}$ Dodi Faedlulloh, "KERJA DALAM KESETARAAN: STUDI PPPK DALAM PROYEKSI KONFIGURASI APARATUR SIPIL NEGARA DI INDONESIA”, Jurnal Civil Service 9, no. 2, (2015): 11-20, 13.

${ }^{9}$ Ibid.
} 
lagi dalam cakrawala kepegawaian di Indonesia. Akan tetapi, di sisi lain, gagasan PPPK yang disinyalir merupakan antitesis dari hilangnya eksistensi tenaga honorer tidak dapat diimplementasikan karena ketiadaan peraturan pelaksananya. Hal demikian tentu saja hanya menimbulkan ketidakjelasan dan ketidakpastian di tengah-tengah belum selesainya problematika seputar tenaga honorer yang belum semua diangkat menjadi CPNS. Untuk melengkapi diskursus pemikiran dalam tulisan ini, pada pembahasan selanjutnya penulis akan menguraikan analisis perihal berbagai problematika dan anomali seputar kehadiran PPPK dalam cakrawala kepegawaian di Indonesia yang tidak kunjung surut hingga kini kendati pasca lahirnya PP Manajemen PPPK, disertai dengan penyampaian solusi untuk mengatasinya.

\section{Anomali Kehadiran PPPK sebagai Upaya Penyelesaian Problematika seputar Tenaga Honorer}

Dalam cakrawala kepegawaian di Indonesia, eksistensi pegawai tidak tetap telah diakui dan mendapatkan legitimasi hukumnya berdasarkan Undang-Undang Nomor 43 Tahun 1999 tentang Pokok-Pokok Kepegawaian dimana disebutkan secara eksplisis verbis bahwa di samping pegawai negeri, juga terdapat pegawai tidak tetap yang dapat diangkat untuk jangka waktu tertentu guna melaksanakan tugas Pemerintahan dan pembangunan yang bersifat teknis profesional dan administrasi sesuai dengan kebutuhan dan kemampuan organisasi. ${ }^{10}$

Untuk perkembangan selanjutnya, Peraturan Pemerintah Nomor 48 Tahun 2005 memperkenalkan istilah baru bagi pegawai tidak tetap yaitu tenaga honorer yang diangkat oleh Pejabat Pembina Kepegawaian atau Pejabat lain dalam Pemerintahan untuk melaksanakan tugas tertentu pada Instansi Pemerintah atau yang penghasilannya menjadi beban APBN atau APBD. ${ }^{11}$ Dalam hal ini, yang menjadi ciri khas dari pegawai tidak tetap atau tenaga honorer adalah hubungan kontraktual yang melandasi eksistensi mereka sehingga istilah 'tenaga kontrak' juga menjadi sapaan yang familiar di kalangan masyarakat dalam cakrawala kepegawaian di Indonesia.

Lahirnya PP Manajemen PPPK yang melarang Pejabat Pembina Kepegawaian (PPK) untuk mengangkat pegawai non-PNS dan/atau non-PPPK tentu saja berimplikasi terhadap hapusnya eksistensi pegawai tidak tetap/tenaga honorer/tenaga kontrak yang sebelumnya diakui. Bertalian dengan hal tersebut, Peraturan Pemerintah a quo mencoba untuk menghadirkan solusi dengan memberikan kesempatan kepada mereka untuk tetap bekerja dalam jangka waktu selama 5 (lima) tahun untuk selanjutnya dapat diangkat menjadi PNS atau PPPK jika memenuhi persyaratan yang telah ditentukan. ${ }^{12}$ Akan tetapi, sampai saat ini, hadirnya PPPK sebagai upaya penyelesaian berbagai problematika seputar tenaga honorer masih belum membuahkan hasil. Hal ini terbukti bahwa sampai saat ini Pemerintah masih

\footnotetext{
${ }^{10}$ Republik Indonesia, Undang-Undang tentang Perubahan Atas Undang-Undang Nomor 8 Tahun 1974 tentang Pokok-Pokok Kepegawaian, UU Nomor 43 Tahun 1999, LN Nomor 169 Tahun 1999, TLN Nomor 3890, Pasal 2 Ayat (3).

${ }^{11}$ Republik Indonesia, Peraturan Pemerintah tentang Pengangkatan Tenaga Honorer Menjadi Calon Pegawai Negeri Sipil, Peraturan Pemerintah Nomor 48 Tahun 2005 sebagaimana telah diubah beberapa kali terakhir dengan Peraturan Pemerintah Nomor 56 Tahun 2012, Pasal 1 Ayat (1).

12 Dalam hal ini, keberadaan PPPK dianggap sebagai problem solving dalam mengatasi permasalahan tenaga honorer yang setiap saat meningkat namun tidak berbasis data dan juga menjadi jalan keluar berbagai permasalahan daerah seputar tenaga honorer yang tidak terkendali. Lihat Tobirin, "TANTANGAN DAN PELUANG PENERAPAN MANAJEMEN BERBASIS KINERJA PADA PEGAWAI PEMERINTAH DENGAN PERJANJIAN KERJA DI DAERAH”, Jurnal Civil Service 9, no. 2, (2015): 71-79, 73.
} 
belum bisa memberikan jaminan kepada tenaga honorer seluruhnya untuk dapat diangkat menjadi CPNS atau Calon PPPK, khususnya bagi tenaga honorer kategori dua. ${ }^{13}$

Jika mengikuti logika berfikir UU ASN, sejatinya, tenaga honorer yang ingin diangkat menjadi CPNS harus mengikuti proses seleksi dan mekanisme yang telah ditentukan, pun sama halnya dengan tenaga honorer yang ingin diangkat menjadi Calon PPPK ${ }^{14}$. Untuk selanjutnya, PPPK pun tidak bisa secara otomatis dapat diangkat menjadi CPNS melainkan harus mengikuti serangkaian proses seleksi CPNS yang telah ditentukan. Hal-hal demikian tentu saja selaras dengan paradigma UU ASN yang menganut merit system untuk mendapatkan pegawai yang kompeten dan profesional yang berbanding lurus antara kualifikasi, kompetensi, dan kinerja yang dibutuhkan oleh jabatan dengan kualifikasi, kompetensi, dan kinerja yang dimiliki oleh pegawai. ${ }^{15}$ Kendati demikian, tujuan tersebut selazimnya harus dikritisi dan diuji kembali jika solusi yang ditawarkan untuk mengakhiri problematika seputar tenaga honorer adalah dengan menghadirkan PPPK dalam cakrawala kepegawaian di Indonesia.

Sebagai contoh, untuk melamar menjadi PPPK dalam Jabatan Fungsional, Pasal 16 huruf $f$ Peraturan Pemerintah tentang Manajemen PPPK mensyaratkan kepemilikan kompetensi yang harus dibuktikan dengan sertifikasi keahlian tertentu yang masih berlaku. Dalam hal ini, guru honorer tentu saja dapat mengikuti seleksi menjadi PPPK jika memiliki kompetensi yang dibuktikan dengan sertifikat keahlian yang masih berlaku yaitu untuk formasi guru harus lulus Pendidikan Profesi Guru dan mempunyai Sertifikat Pendidik. Jika honorer kategori dua tidak mempunyai sertifikasi kompetensi tersebut, tentu saja ia tidak bisa mengikuti seleksi. Dengan demikian, maka tenaga honorer yang ingin menjadi PPPK sejatinya terikat dengan ketentuan persyaratan lolos seleksi administrasi maupun seleksi kompetensi.

Dengan ditetapkannya batas waktu penyelesaian problematika seputar tenaga honorer selama 5 (lima) tahun sampai tahun 2023 (berdasarkan PP Manajemen PPPK), selazimnya Pemerintah dalam setiap tahunnya melaksanakan rekrutmen PPPK untuk tenaga honorer sampai selesai, tidak hanya membuka lowongan CPNS saja sehingga nasib para tenaga honorer sampai saat ini masih terombang-ambing. Hal krusial penyebab dilematisasi ini adalah belum dikeluarkannya Peraturan Presiden yang akan menentukan jabatan apa saja yang dapat diisi oleh PPPK yang kemudian mendorong Pemerintah untuk melaksanakan rekrutmen PPPK. Kendati demikian, Pemerintah tetap harus menghapus eksistensi tenaga honorer dari cakrawala kepegawaian di Indonesia berdasarkan logika berfikir UU ASN.

Tidak berhenti sampai di sini, ketentuan peralihan yang tidak mengatur perihal status tenaga honorer tentu saja berkontribusi pada kekosongan hukum (legal vacuum) terhadap eksistensi tenaga honorer yang telah diakui selama ini. Hemat penulis, pada titik inilah kehadiran PPPK dalam cakrawala kepegawaian di Indonesia sebagai upaya penyelesaian problematika seputar tenaga honorer hanyalah suatu anomali. Dalam hal ini, para pembentuk undang-undang seharusnya lebih berhati-hati dalam merubah dan merumuskan ketentuan norma dalam regulasi baru yang secara sekuensial juga berkontribusi pada ketidakpastian hukum (legal uncertainty) terhadap para pihak yang telah diatur dalam regulasi lama. Dalam

\footnotetext{
${ }^{13}$ Berdasarkan Surat Edaran Menteri Negara Pendayagunaan Aparatur Negara dan Reformasi Birokrasi Nomor 5 Tahun 2010 tentang Pendataan Tenaga Honorer yang Bekerja di Lingkungan Instansi Pemerintah, tenaga honorer kategori dua adalah tenaga honorer yang penghasilannya dibiayai bukan dari APBN atau APBD.

${ }^{14}$ Pasal 2 Ayat (1) Peraturan Pemerintah tentang Manajemen PPPK menentukan bahwa jabatan ASN yang dapat diisi oleh PPPK meliputi: (a) Jabatan Fungsional; dan (b) Jabatan Pimpinan Tinggi.

15 Henny Juliani, "DISKRESI DALAM REKRUTMEN PEGAWAI NON PEGAWAI NEGERI SIPIL SETELAH PEMBERLAKUAN PERATURAN PEMERINTAH NOMOR 49 TAHUN 2018 TENTANG MANAJEMEN PEGAWAI PEMERINTAH DENGAN PERJANJIAN KERJA", Administrative Law and Governance Journal 2, no. 2, (2019): 314-325, 322, DOI: 10.14710/alj.v2i2.314\%20-\%20325.
} 
situasi dan kondisi seperti ini, pengaturan perihal kebersinambungannya dalam peraturan perundang-undangan menjadi conditio sine qua non dalam upaya penyelesaian problematika seputar tenaga honorer.

\section{Anomali Pengisian Jabatan ASN oleh PPPK, Penilaian Kinerja dan Pengembangan Kompetensi PPPK}

Terdapat diferensiasi mendasar dalam UU ASN perihal pengaturan mengenai pengisian Jabatan Pimpinan Tinggi bagi kalangan PNS dan PPPK. ${ }^{16}$ Problematika yang muncul kemudian adalah ketika seorang PPPK mengisi jabatan pimpinan tinggi sehingga dapat mengambil kebijakan strategis yang mungkin berdampak pada perubahan status hukum dalam aspek organisasi, kepegawaian, dan alokasi anggaran. Jika menilik status PPPK yang sejatinya hanyalah merupakan pegawai tidak tetap yang sewaktu-waktu dapat memutus hubungan kerja atas permintaan sendiri, bagaimana regenerasi pekerjaan dalam suatu Instansi tersebut dan bagaimana dengan sumpah untuk memegang rahasia jabatan atau kedinasan yang menurut sifatnya atau menurut perintah harus dirahasiakan?

Selanjutnya, mengenai pengaturan perihal penilaian kinerja PPPK yang dapat dinilai sebagai langkah tegas untuk memastikan profesionalitas PPPK dalam bekerja, hal ini tentu saja menjadi tantangan tersendiri bagi para pemangku kepentingan (stakeholders) sehingga komitmen mereka untuk dapat terus mengawasi pelaksanaannya adalah suatu keniscayaan. Lebih lanjut, hasil dari penilaian kinerja PPPK yang menentukan kesempatan untuk pengembangan kompetensi PPPK seolah-olah memberikan angin segar akan kepedulian Pemerintah terhadap kompetensi PPPK. Dalam hal ini, yang menjadi problematika selanjutnya adalah bahwa sesungguhnya hal tersebut tidaklah berpengaruh sama sekali terhadap pengembangan karir PPPK yang memang tidak memiliki kesempatan untuk menempuh jenjang karir. Pengembangan kompetensi bagi PPPK ini sesungguhnya hanyalah berpengaruh terhadap peningkatan kompetensi dan kemampuan mereka yang bertalian dengan profesionalitas bekerja. ${ }^{17}$

Sehubungan dengan hal tersebut, pengembangan kompetensi bagi PNS mungkin dapat dijadikan sebagai investasi di bidang SDM dengan harapan feed back yang dapat diberikan bagi suatu Instansi mengingat status PNS yang bersifat tetap. Akan tetapi, berbeda halnya dengan pengembangan kompetensi bagi PPPK, sangat sulit untuk mengatakan bahwa hal tersebut merupakan investasi SDM mengingat status PPPK yang tidak tetap dan dapat berhenti dengan berakhirnya perjanjian kerja. Dalam narasi yang lebih tegas, hasil dari pendidikan dan pelatihan yang merupakan bagian dari pengembangan kompetensi bagi PPPK hanya akan dibawa oleh yang bersangkutan ke Instansi lain. ${ }^{18}$ Pada titik inilah penulis berpendapat bahwa pengaturan mengenai pengisian jabatan ASN oleh PPPK serta penilaian kinerja dan pengembangan kompetensi PPPK sejatinya hanyalah merupakan suatu anomali.

Tidak berhenti sampai di situ, jika mengacu pada logika berfikir UU ASN dan PP Manajemen PPPK, sejatinya di dalam manajemen PPPK tidak dikenal adanya pengembangan karir, kenaikan pangkat, dan promosi. Hal demikian menyiratkan bahwa seseorang mungkin saja dikontrak untuk pekerjaan yang sama seumur hidupnya. Mengingat suatu pekerjaan

\footnotetext{
${ }^{16}$ Dalam hal ini, PNS dapat mengisi seluruh Jabatan ASN yang di antaranya yaitu JPT Utama, Madya, dan Pratama. Sedangkan PPPK hanya dapat mengisi JPT Utama dan Madya tententu saja, itu pun harus terlebih dahulu mendapatkan persetujuan Presiden yang ditetapkan dalam Keputusan Presiden. Lihat Republik Indonesia, Undang-Undang tentang Aparatur Sipil Negara, UU Nomor 5 Tahun 2014, LN Nomor 6 Tahun 2014, TLN Nomor 5494, Pasal 108 dan 109.

17 Tri Widhi Ayusari, dkk., "PENGANGKATAN PEGAWAI PEMERINTAH DENGAN PERJANJIAN KERJA (PPPK) DAN IMPLIKASINYA TERHADAP HAK DAN KEWAJIBAN KEPEGAWAIAN", Soedirman Law Review 2, no. 1 (2020): 49-71, 68.

${ }^{18}$ Rike Anggun Artisa, Op.Cit., 40.
} 
sangat berpengaruh terhadap kehidupan seseorang dalam tali temalinya dengan gaji dan tunjangan, maka orang tersebut hanya akan memperoleh gaji dan tunjangan yang sama sepanjang kontrak. Sebaik apapun kinerja seorang PPPK, hal tersebut sesungguhnya tidak akan berpengaruh sama sekali terhadap jenjang karir dan kenaikan pangkatnya mengingat PPPK tidak berhak untuk itu.

Selanjutnya, implikasi dikotonomis PNS dan PPPK dalam tubuh kepegawaian di Indonesia sesungguhnya telah melanggar beberapa asas penyelenggaraan ASN dalam UU ASN. Dalam hal ini, dikotonomi PNS dan PPPK tanpa didasari sifat dan jenis pekerjaan yang jelas merupakan pelanggaran terhadap asas keterpaduan mengingat asas keterpaduan menghendaki pengelolaan ASN yang terpadu secara nasional. Dalam praktiknya, dikotonomi ini hanya akan melahirkan sistem kepegawaian yang diskriminatif dan tidak berdasar pada sistem merit (merit system). Lebih lanjut, dikotomi tersebut juga telah melahirkan perbedaan kesempatan dan hak yang tentu saja melanggar asas keadilan dan kesetaraan. Sebagaimana terdapat beberapa kesempatan dan hak yang hanya diperuntukkan bagi kalangan PNS namun tidak untuk kalangan PPPK. Kesempatan dan hak dimaksud adalah kesempatan dan hak untuk berkompetisi menjadi pejabat pimpinan tinggi, pengembangan karir, kenaikan pangkat dan promosi serta dalam hal jaminan pensiun. Ketiadaan akan kesempatan dan hak-hak tersebut sejatinya juga merupakan pelanggaran terhadap asas kesejahteraan.

Hemat penulis, hal-hal inilah yang perlu menjadi pertimbangan khusus bagi pemerintah dan para pemangku kepentingan (stakeholder) untuk segera membuat peraturan pelaksana yang lebih khusus dan terperinci guna mengatasi berbagai problematika dimaksud sehingga kehadiran PPPK dalam cakrawala kepegawaian di Indonesia tidak hanya menjadi suatu anomali. Selain itu, hal ini juga tentu saja dalam rangka dan upaya pelaksanaan reformasi birokrasi sebagai ratio legis dari lahirnya UU ASN.

\section{Anomali Sistem Penggajian PPPK}

Di dalam Undang-Undang tentang Aparatur Sipil Negara, ditentukan bahwa PPPK diberikan gaji berdasarkan beban kerja, tanggung jawab jabatan dan resiko pekerjaan ${ }^{19}$ yang dibebankan pada APBN untuk PPPK di Instansi Pusat dan APBD untuk PPPK di Instansi Daerah. $^{20}$ Selain gaji, PPPK juga berhak menerima tunjangan sesuai dengan ketentuan peraturan perundang-undangan. ${ }^{21}$ Dari sini terlihat bahwa sistem penggajian PPPK dari APBN dan APBD yang didasarkan pada beban kerja, tanggung jawab jabatan dan resiko pekerjaan juga telah diupayakan untuk menggunakan merit system. Akan tetapi terdapat dikotomi antara PNS dan PPPK bertalian dengan jaminan pensiun dan jaminan hari tua.

Sehubungan dengan hal tersebut, tunjangan-tunjangan yang diterima oleh PPPK diintegrasikan dalam sistem jaminan sosial nasional. ${ }^{22}$ Pada titik inilah munculnya kesenjangan antara PNS dan PPPK dikarenakan keberadaan PNS di kelas yang lebih baik. Problematika inilah yang benar-benar harus menjadi fokus utama Pemerintah dalam perbaikan manajemen PPPK untuk meyakinkan masyarakat bahwa posisi PPPK dalam tubuh kepegawaian di Indonesia adalah posisi yang menarik. Selain itu, kesenjangan antara PNS dan PPPK dalam hal diferensiasi fasilitas dan tunjangan juga harus segera diatasi dengan perbaikan manajemen PPPK berbasis keadilan yang tentu saja juga harus dilandasi dengan pertimbangan kemampuan organisasi.

Dalam narasi yang lebih optimis, analisis rasio beban kerja disertai dengan perimbangan jumlah layanan dan fungsi administrasi dengan jumlah PNS serta urgensi pengadaan,

\footnotetext{
${ }^{19}$ Republik Indonesia, Undang-Undang tentang Aparatur Sipil Negara, UU Nomor 5 Tahun 2014, LN Nomor 6 Tahun 2014, TLN Nomor 5494, Pasal 101 Ayat (2).

${ }^{20}$ Ibid., Pasal 101 Ayat (3).

${ }^{21}$ Ibid., Pasal 101 Ayat (4).

${ }^{22}$ Ibid., Pasal 106 Ayat (1) dan (2).
} 
penempatan dan proporsi jumlah PPPK harus benar-benar diperhitungkan secara matang untuk mengantisipasi inefisiensi dan pembengkakan anggaran belanja pegawai. Selain itu, manajemen PNS dan PPPK dalam kerangka Undang-Undang Aparatur Sipil Negara yang bertalian dengan proporsi ideal jumlah pegawai juga harus benar-benar dipertimbangkan dengan kondisi beban fiskal serta tujuan peningkatan pelayanan publik dan pembangunan. ${ }^{23}$ Hal demikian selain dalam upaya mencegah terjadinya defisit pendanaan dan anggaran juga mencegah terjadinya anomali dari kehadiran PPPK dalam cakrawala kepegawaian di Indonesia.

\section{Anomali Penetapan Kebutuhan dan Pengadaan PPPK}

Sesungguhnya, kehadiran PPPK dalam cakrawala kepegawaian di Indonesia bertujuan untuk membantu mengatasi kebutuhan akan pegawai yang kompeten dan profesional dalam rangka peningkatan kualitas birokrasi kendati malah menimbulkan berbagai problematika baru dalam cakrawala yang sama. Perekrutan tenaga honorer yang sebelumnya acapkali diwarnai dengan alasan nepotis dan motif politis dari berbagai pihak tanpa melalui seleksi yang ketat dan transparan hanyalah menghasilkan pegawai dengan kompetensi yang rendah dan profesionalitas yang minim. ${ }^{24}$

Dalam hal ini, Undang-Undang Aparatur Sipil Negara sesungguhnya telah berupaya untuk mengatasi problematika tersebut dimana analisis jabatan dan analisis beban kerja menjadi pertimbangan mendasar dalam penyusunan kebutuhan jumlah dan jenis jabatan PPPK untuk jangka waktu selama lima tahun yang selanjutnya diperinci per satu tahun berdasarkan prioritas kebutuhan. ${ }^{25}$ Lebih lanjut, penilaian secara objektif berdasarkan kompetensi, kualifikasi dan kebutuhan Instansi juga menjadi pertimbangan mendasar dalam melaksanakan penerimaan calon PPPK. ${ }^{26}$ Ketentuan norma ini menyiratkan bahwa UndangUndang a quo telah membangun fondasi bagi penerapan merit system dimana PPPK tidak diperkenankan secara otomatis direkrut dan diangkat melainkan harus mengikuti serangkaian proses seleksi. Tidak ada otomatisasi pengangkatan tanpa adanya seleksi. ${ }^{27}$

Problematika yang muncul kemudian adalah berkembangnya stigma negatif terhadap proses rekrutmen PPPK dengan kesan 'carut marut' yang hanya akan melahirkan pegawai birokrasi dengan kinerja yang tidak baik. ${ }^{28}$ Pada titik inilah proses rekrutmen dan pengadaan PPPK hanya menjadi suatu anomali. Untuk mengatasinya, analisis yang menyeluruh terhadap keseimbangan antara kebutuhan pekerjaan dengan komposisi PPPK disertai pertimbangan anggaran adalah sebuah keniscayaan yang benar-benar harus dipertimbangkan secara matang untuk menghasilkan PPPK yang memiliki kejelasan posisi dan fungsi dalam rangka melaksanakan tugas pemerintahan dan pelayanan publik.

\section{Anomali Pemutusan Hubungan Kerja dan Status Kepegawaian PPPK}

Pengangkatan PPPK ditetapkan dengan keputusan Pejabat Pembina Kepegawaian (PPK) dengan masa kerja tertentu yaitu paling singkat 1 (tahun) dan dapat diperpanjang berdasarkan kebutuhan dan penilaian kinerja. ${ }^{29}$ Ketentuan ini menyiratkan bahwa masa kerja

\footnotetext{
${ }^{23}$ Joko Tri Haryanto, Op. Cit., 42.

24 Rike Anggun Artisa, Op. Cit., 37-38.

${ }^{25}$ Republik Indonesia, Undang-Undang tentang Aparatur Sipil Negara, UU Nomor 5 Tahun 2014, LN Nomor 6 Tahun 2014, TLN Nomor 5494, Pasal 94.

${ }^{26}$ Ibid, Pasal 97.

${ }^{27}$ Wawanudin dan Rohidin Sudarno, "PELAKSANAAN SISTEM MERIT DALAM UU ASN, WEWENANG KASN DAN ANALISIS PERATURAN PERUNDANG-UNDANGAN YANG BERPENGARUH TERHADAP WEWENANG KASN", Jurnal Mozaik 10, no. 1, (2018): 26-40, 32.

${ }^{28}$ Rike Anggun Artisa, Op. Cit., 38.

${ }^{29}$ Republik Indonesia, Undang-Undang tentang Aparatur Sipil Negara, UU Nomor 5 Tahun 2014, LN Nomor 6 Tahun 2014, TLN Nomor 5494, Pasal 98.
} 
PPPK berakhir seiring dengan berakhirnya masa perjanjian kerja atau jika kinerja PPPK dimaksud tidak menunjukkan hasil yang baik. Namun, ditentukannya batas minimal masa kerja PPPK tanpa adanya ketentuan batas maksimal masa kerja tentu saja menjadi problematika tersendiri perihal kejelasan dan kepastian masa kerja. Untuk mengatasinya, batas maksimal masa kerja PPPK perlu ditentukan untuk memberikan kepastian dan menghindari kemungkinan terjadinya politisasi perpanjangan hubungan perjanjian kerja PPPK.

Sehubungan dengan hal tersebut, jika mengacu pada ketentuan Peraturan Pemerintah tentang Manajemen PPPK, ditentukan bahwa perpanjangan hubungan perjanjian kerja dapat diberikan paling lama 5 (lima) tahun untuk PPPK yang menduduki JPT baik Utama maupun Madya. Namun, tidak ada ketentuan yang mengatur perpanjangan hubungan perjanjian kerja bagi PPPK yang tidak menduduki JPT. Hal inilah yang juga berkontribusi pada ketidakjelasan status kepegawaian PPPK sehingga menjadi legitimasi bagi Pejabat Pembina Kepegawaian (PPK) untuk memutuskan hubungan perjanjian kerja PPPK. ${ }^{30}$ Hemat penulis, masa hubungan perjanjian kerja PPPK perlu menjadi perhatian khusus pemerintah dalam memberikan perlindungan terhadap pemenuhan hak-hak PPPK.

Selanjutnya, hal yang juga perlu mendapatkan perhatian khusus adalah pemutusan hubungan kerja karena perampingan organisasi atau pengurangan PPPK sebagai akibat dari kebijakan pemerintah. ${ }^{31}$ Dalam hal ini, kompensasi apakah yang akan diterima oleh PPPK jika terjadi pemutusan hubungan kerja secara sepihak. Ketidakpastian dan ketidakjelasan ini sesungguhnya hanyalah mengurangi daya tarik masyarakat untuk menjadi seorang PPPK dan tentu saja sangat mempengaruhi motivasi kerja PPPK. Problematika inilah yang juga harus segera diatasi oleh pemerintah dengan otoritas dan kewenangan legislasi yang dimilikinya.

Selain itu, keberlangsungan sistem hubungan kerja dengan perjanjian kerja sebenarnya bukanlah merupakan hal yang baru dalam cakrawala kepegawaian di Indonesia. Perjanjian Kerja dengan Waktu Tertentu (PKWT) telah diatur berdasarkan Undang-Undang Nomor 13 Tahun 2003 tentang Ketenagakerjaan ${ }^{32}$ dan telah digunakan di dalam sistem perburuhan di Indonesia yang sudah berlangsung sejak lama. Adapun penggunaannya dalam birokrasi didasari oleh preseden buruk yang pernah terjadi dalam dinamika kepegawaian di Indonesia ketika dengan berlandaskan Peraturan Pemerintah Nomor 48 Tahun 2005, sistem pengangkatan tenaga honorer menjadi CPNS menuai banyak kritik karena tidak mencerminkan kebutuhan riil dan tidak sesuai dengan merit system sehingga berkontribusi pada bengkaknya anggaran belanja pegawai yang bahkan mengalahkan besaran anggaran pembangunan. ${ }^{33}$

Tidak berhenti sampai di situ, pengangkatan tenaga honorer menjadi CPNS juga menuai berbagai problematika seputar penentuan usia dalam kaitannya dengan masa kerja, kewenangan penentuan daerah terpencil atau tertinggal beserta kriterianya, hingga pembebanan biaya pelaksanaan. ${ }^{34}$ Terhadap problematika tersebut, penerapan merit system dalam pengangkatan pegawai tidak tetap merupakan sebuah solusi untuk mengatasinya. Dengan telah diaturnya PPPK dalam UU ASN, maka pengaturan mengenai PPPK tidak tunduk pada ketentuan Undang-Undang Nomor 13 Tahun 2003 tentang Ketenagakerjaan

\footnotetext{
${ }^{30}$ Dwi Aryanti Ramadhani dan Iwan Erar Joesoef, "PERLINDUNGAN HUKUM PEGAWAI PEMERINTAH DENGAN PERJANJIAN KERJA (PPPK) DALAM KONSEP PERJANJIAN KERJA WAKTU TERTENTU DI INSTITUSI PERGURUAN TINGGI", Jurnal Yuridis 7, no. 1 (2020): 1-26, 23, DOI: 10.35586/jyur.v7i1.1308.

${ }^{31}$ Republik Indonesia, Undang-Undang tentang Aparatur Sipil Negara, UU Nomor 5 Tahun 2014, LN Nomor 6 Tahun 2014, TLN Nomor 5494, Pasal 105 Ayat (1).

${ }^{32}$ Republik Indonesia, Undang-Undang tentang Ketenagakerjaan, UU Nomor 13 Tahun 2003, LN Nomor 39 Tahun 2003, TLN Nomor 4279, Pasal 56 Ayat (2).

${ }^{33}$ Rike Anggun Artisa, Op. Cit., 40.

${ }^{34}$ Novi Savarianti Fahrani, "MANAJEMEN PEGAWAI PEMERINTAH DENGAN PERJANJIAN KERJA DI PEMERINTAH KOTA BANDA ACEH”, Jurnal Civil Service 9, no. 2 (2015): 55-70, 62.
} 
meskipun sama-sama menggunakan sistem perjanjian kerja dengan waktu tertentu. Dalam hal ini, pengaturan mengenai PPPK tunduk pada dan diatur dalam ranah hukum publik oleh Undang-Undang Nomor 5 Tahun 2014 tentang Aparatur Sipil Negara. ${ }^{35}$

Lebih lanjut, dalam hal status kepegawaian, tentu saja status kepegawaian PNS dan PPPK jelas berbeda. Regulasi yang berlaku bagi PNS pun tidak secara otomatis berlaku bagi PPPK. Dengan kekuatan hukum yang dimilikinya, PNS dapat mengambil kebijakan berdasarkan kewenangannya. Di sisi lain, PPPK hanyalah pegawai pemerintah dengan keahlian khusus yang dimiliki dan bertugas sebagai pelaksana. ${ }^{36}$ Dalam hal ini, diferensiasi mendasar antara PNS dan PPPK adalah hubungan hukumnya. Status kepegawaian PNS adalah sebagai pegawai tetap yang masa berakhirnya adalah batas usia pensiun, sedangkan status kepegawaian PPPK berakhir melalui pemutusan hubungan kerja.

Problematika selanjutnya perihal pengaturan PPPK dalam UU ASN adalah dimungkinkannya bagi PNS yang sudah pensiun untuk menjadi PPPK dengan memenuhi persyaratan tertentu seperti memiliki kompetensi yang dibutuhkan dan tidak melampaui batas usia maksimal. Adanya pengaturan seperti ini tentu saja berkontribusi pada terhambatnya regenerasi suatu instansi karena yang bekerja di tempat tersebut hanyalah orang-orang yang sama. Bagaimanakah ketentuan ini akan memberikan rasa keadilan mengingat ruang dan kesempatan bagi masyarakat untuk menjadi PPPK menjadi berkurang?

Terakhir, dalam tali temalinya dengan status hukum dan hubungan hukum PPPK yang hanya sebatas hubungan hukum secara perdata (kontraktual), maka dalam hal ini sangat diperlukan kejelasan dari sisi pengaturan dan kesepakatan dari sejak rekrutmen sampai bagaimana hubungan kerja berakhir. Selain itu, juga perlu ditetapkan secara jelas dan tegas dari awal mengenai jenis pekerjaan dan hak serta kewajiban Pegawai Pemerintah dengan Perjanjian Kerja (PPPK). Dengan begitu, maka kepastian secara hukum bagi Pegawai Pemerintah dengan Perjanjian Kerja (PPPK) dalam bekerja dan menjalani masa hubungan kerja akan tercipta. ${ }^{37}$

\section{Persinggungan Eksistensi PPPK dengan Eksistensi Tenaga Ahli}

Setelah menguraikan berbagai problematika dan anomali seputar kehadiran PPPK dalam cakrawala kepegawaian di Indonesia, pada pembahasan ini penulis ingin mempersinggungkan eksistensi PPPK dengan eksistensi Tenaga Ahli mengingat keduanya memiliki karakteristik yang sama, sebagai upaya menguji keberlangsungan dan kesinambungan gagasan lahirnya PPPK dalam cakrawala kepegawaian di Indonesia sebagai suatu anomali. Untuk memfokuskan diskursus pemikiran dalam tulisan ini, penulis mendasarkan persinggungannya dengan Tenaga Ahli Anggota DPR dimana eksistensinya masih tetap berlangsung hingga kini dan diakui di dalam peraturan perundang-undangan.

Jika ditilik secara historis, sejak tahun 2003 Sekretariat Jenderal DPR sudah menyediakan anggaran untuk pengadaan satu asisten pribadi bagi setiap anggota legislatif sebagai bagian dari supporting system parliament yang bertujuan untuk meningkatkan kinerja anggota dewan. ${ }^{38}$ Dalam praktiknya, asisten pribadi tersebut dibayar oleh Sekretariat Jenderal DPR

\footnotetext{
${ }^{35}$ Terdapat pandangan yang melihat bahwa keberadaan PPPK secara hukum adalah di tengah-tengah antara hukum publik dan hukum privat. Jika didudukkan dalam status hukum privat maka berkonsekuensi pada hak sebagai tenaga kerja swasta, memiliki hubungan industrial, negosiasi gaji dan tunjangan serta hak ketenagakerjaan lainnya. Dalam status ini, UU Ketenagakerjaan akan mengikat bagi PPPK. Lihat Wawanudin dan Rohidin Sudarno, Op. Cit., 34.

${ }^{36}$ Edi Siswadi, Birokrasi Masa Depan Menuju Tata Kelola Pemerintahan yang Efektif dan Prima, (Bandung: Mutiara Press, 2012), 156.

${ }^{37}$ Sri Hartini, dkk., Hukum Kepegawaian di Indonesia, Cetakan Ketiga, (Jakarta: Sinar Grafika, 2014), hal. 31.

${ }^{38}$ Ziegenhain dalam Marco Bunte dan Andreas Ufen (Eds.), Democratization in Post-Soeharto Indonesia, (London: Routledge, 2009), 44.
} 
yang tentu saja pendanaannya berasal dari APBN untuk membantu kinerja para anggota legislatif dalam menjalankan fungsi legislasinya.

Selanjutnya pada tahun 2007, Sekretariat Jenderal DPR kembali memberikan fasilitas satu tenaga ahli kepada setiap legislator yang dimaksudkan untuk mendongkrak kinerja lembaga legislatif yang belum membaik. Rekrutmen dilakukan dengan mengadakan serangkaian tes administrasi, wawancara, dan psikologi. Tenaga ahli tersebut berstatus kontrak selama satu tahun dan dievaluasi di tiap tahunnya. ${ }^{39}$ Dalam perkembangan selanjutnya, payung hukum yang kuat untuk menaungi eksistensi tenaga ahli anggota legislatif baru ada pada tahun 2009 ketika eksistensinya dimasukkan secara normatif ke dalam ketentuan Pasal 80 Ayat (6) dan Pasal 395 Ayat (1) dan (2) Undang-Undang Nomor 27 Tahun 2009 tentang MPR, DPR, DPD, dan DPRD.

Ketentuan normatif tersebut untuk selanjutnya diturunkan ke dalam peraturan yang lebih rendah, yaitu Peraturan Tata Tertib DPR Tahun 2009 Pasal 293 Ayat (1) sampai dengan Ayat (8). Dalam ketentuan tersebut, dijelaskan bahwa anggota dewan memiliki otoritas untuk mengusulkan calon tenaga ahli sesuai dengan kebutuhannya. Tenaga ahli bertanggung jawab kepada anggota dan bisa diberhentikan oleh Sekretaris Jenderal DPR atas usul dari anggota dewan. Surat Keputusan pengangkatan tenaga ahli berlaku kontrak selama satu tahun dan diadakan evaluasi di akhir tahunnnya. Jika anggota dewan yang bersangkutan tidak mempermasalahkan kinerja tenaga ahli dalam evaluasi tahunan tersebut, maka kontrak akan diperpanjang selama satu tahun berikutnya.

Sejak awal tahun 2011, Sekretariat Jenderal DPR menambah lagi fasilitas satu orang tenaga ahli untuk setiap legislator. Hingga kini, setiap anggota legislatif memiliki dua tenaga ahli yang dibiayai dari anggaran Sekretariat Jenderal DPR. ${ }^{40}$ Dewasa ini, ketentuan normatif perihal tenaga ahli anggota legislatif tertuang dalam Undang-Undang Nomor 17 Tahun 2014 tentang MPR, DPR, DPD, dan DPRD dalam Bab VII tentang Sistem Pendukung dimana dalam Pasal 415 disebutkan bahwa Pegawai Sekretariat Jenderal DPR RI terdiri atas Pegawai Negeri Sipil (PNS) dan Pegawai Tidak Tetap. Selanjutnya, Pasal 416 mengatur mengenai kelompok pakar atau Tim Ahli sedangkan Paragraf 5 Pasal 417 mengatur mengenai Tenaga Ahli yang di antaranya meliputi Tenaga Ahli alat kelengkapan DPR, Tenaga Ahli anggota DPR, dan Tenaga Ahli Fraksi.

Sejatinya, berdasarkan ketentuan peraturan perundang-undangan tersebut, eksistensi Tenaga Ahli Anggota DPR sebagai orang yang bekerja bukan pada Instansi Swasta, sangatlah bersinggungan dan tidak bisa terlepas dari ketentuan Undang-Undang Aparatur Sipil Negara. Dalam artian, karakteristik Tenaga Ahli Anggota DPR sangat serupa dengan karakteristik PPPK. Akan tetapi, diferensiasi yang paling mendasar adalah bahwa di dalam pelaksanaannya, eksistensi Tenaga Ahli anggota legislatif sudah berjalan sejak lama secara berkesinambungan dan memiliki payung hukum yang menaunginya. Berbeda halnya dengan pelaksanaan PPPK yang masih 'carut marut' dan hanya diselimuti dengan berbagai problematika. Jika terus seperti ini, penulis menegaskan bahwa seiring dengan berjalannya waktu, eksistensi PPPK hanya akan tenggelam ditelan permasalahan. Dengan demikian, upaya menghentaskan 'carut marut' kompetensi dan profesionalitas SDM Aparatur Negara dalam tubuh birokrasi di Indonesia dengan hadirnya PPPK hanyalah suatu anomali yang tidak berarti.

Sebaliknya, jika berbagai problematika tersebut dapat segera diatasi oleh Pemerintah dengan kekuasaan dan kewenangan legislasi yang dimilikinya, maka bukan tidak mungkin stigma 'anomali' yang menyelimuti akan berganti menjadi 'solusi'. Kehadiran PPPK dalam

\footnotetext{
39 Yogi Setya Permana dan Pandu Yuhsina Adaba, "MENELISIK PERAN TENAGA AHLI ANGGOTA LEGISLATIF”, Jurnal Penelitian Politik 8, no. 1 (2011): 83-94, 87.

${ }^{40}$ Ibid., 88 .
} 
cakrawala kepegawaian di Indonesia dapat menjadi suatu alternatif solusi dalam pemenuhan kekurangan pegawai melalui pegawai non-PNS yang diharapkan dapat dilaksanakan secara profesional, transparan dan objektif, serta bebas dari intervensi politik dan bersih dari KKN sehingga tidak dapat dijadikan sebagai sarana dan alat politik untuk kepentingan kelompok atau golongan tertentu. ${ }^{41}$

\section{Kesimpulan}

Hadirnya PPPK dalam cakrawala kepegawaian di Indonesia yang diinisiasi oleh hadirnya UU ASN dan menjadi bagian dari Pegawai ASN sejatinya merupakan bagian dari agenda reformasi birokrasi yang disinyalir mampu mengakomodir SDM yang unggul dan profesional untuk menjawab 'carut marut' kompetensi dan profesionalitas SDM Aparatur Negara dalam tubuh birokrasi di Indonesia. Kendati demikian, kehadiran PPPK menjadi suatu anomali karena berbagai problematika yang menyelimutinya dalam implementasinya. Anomali kehadiran tersebut di antaranya meliputi upaya penyelesaian problematika seputar tenaga honorer, pengisian jabatan ASN oleh PPPK, penilaian kinerja dan pengembangan kompetensi PPPK, sistem penggajian PPPK, penetapan kebutuhan dan pengadaan PPPK, serta pemutusan hubungan kerja dan status kepegawaian PPPK.

Dalam persinggungannya dengan Tenaga Ahli, terdapat diferensiasi yang paling mendasar dalam implementasinya dimana eksistensi Tenaga Ahli Anggota DPR misalnya, sudah berjalan sejak lama secara berkesinambungan dengan payung hukum yang menaunginya. Pada titik inilah jika berbagai problematika tersebut tidak segera diatasi, maka seiring berjalannya waktu eksistensi PPPK hanya akan tenggelam ditelan permasalahan. Terhadap hal-hal tersebut, penulis menawarkan solusi dan memberikan saran agar kiranya Pemerintah (dalam hal ini Presiden) sebagai pembentuk undang-undang dan para pemangku kepentingan (stakeholders) lainnya agar segera menetapkan peraturan pelaksana yang lebih khusus dan terperinci dalam upaya memaksimalkan perekrutan PPPK untuk memenuhi kekurangan pegawai melalui pegawai non-PNS yang diharapkan dapat dilaksanakan secara profesional, transparan dan objektif, serta bebas dari intervensi politik dan bersih dari KKN. Hal demikian tentu saja dapat dinilai mampu memberikan keadilan dan kepastian hukum bagi PPPK dan tenaga honorer/pegawai tidak tetap lainnya yang selama ini telah ada dan diakui.

\section{A. Jurnal}

\section{DAFTAR PUSTAKA}

Artisa, Rike Anggun. "PEGAWAI PEMERINTAH DENGAN PERJANJIAN KERJA (PPPK): REVIEW TERHADAP UNDANG-UNDANG NOMOR 5 TAHUN 2014 TENTANG APARATUR SIPIL NEGARA". Jurnal Pembangunan dan Kebijakan Publik 6, no. 1, 2015: 33-42.

Ayusari, Tri Widhi, dkk., "PENGANGKATAN PEGAWAI PEMERINTAH DENGAN PERJANJIAN KERJA (PPPK) DAN IMPLIKASINYA TERHADAP HAK DAN KEWAJIBAN KEPEGAWAIAN", Soedirman Law Review 2, no. 1, 2020: 49-71.

Bunte, Marco., Ufen, Andreas. Democratization in Post-Soeharto Indonesia, London: Routledge, 2009.

Faedlulloh, Dodi. "KERJA DALAM KESETARAAN: STUDI PPPK DALAM PROYEKSI KONFIGURASI APARATUR SIPIL NEGARA DI INDONESIA", Jurnal Civil Service 9, no. 2, 2015: 11-20.

\footnotetext{
${ }^{41}$ Harry Susan Pujiraharjo, "PEGAWAI PEMERINTAH DENGAN PERJANJIAN KERJA (PPPK): SOLUSI DALAM REKRUTMEN PEGAWAI DARI PEGAWAI NON PNS ASN", Jurnal Civil Service 9, no. 2, (2015): 21-30, 28.
} 
Fahrani, Novi Savarianti, "MANAJEMEN PEGAWAI PEMERINTAH DENGAN PERJANJIAN KERJA DI PEMERINTAH KOTA BANDA ACEH", Jurnal Civil Service 9, no. 2, 2015: 55-70.

Ghufron, Ahmad, et al., Hukum Kepegawaian di Indonesia, Cetakan Pertama, Jakarta: Rineka Cipta, 1991.

Harahap, Nurmalita Ayuningtyas. "PERLINDUNGAN HUKUM PEGAWAI PEMERINTAH DENGAN PERJANJIAN KERJA UNTUK MEWUJUDKAN REFORMASI BIROKRASI", Jurnal Hukum Justitia Et Pax 32, no. 2, 2016: 13-31.

Haryanto, Joko Tri. "ANALISIS BEBAN FISKAL MANAJEMEN PEGAWAIA PEMERINTAH DENGAN PERJANJIAN KERJA”, Jurnal Civil Service 9, no. 2, 2015: $31-44$.

Juliani, Henny. "DISKRESI DALAM REKRUTMEN PEGAWAI NON PEGAWAI NEGERI SIPIL SETELAH PEMBERLAKUAN PERATURAN PEMERINTAH NOMOR 49 TAHUN 2018 TENTANG MANAJEMEN PEGAWAI PEMERINTAH DENGAN PERJANJIAN KERJA", Administrative Law and Governance Journal 2, no. 2, 2019: 314-325, DOI: 10.14710/alj.v2i2.314\%20-\%20325.

Lohida, Leni, “ANALISIS KOMPARASI PEGAWAI PEMERINTAH DENGAN PERJANJIAN KERJA (PPPK) DALAM PARADIGMA UNDANG-UNDANG NOMOR 5 TAHUN 2014 TENTANG APARATUR SIPIL NEGARA", Jurnal Civil Service 9, no. 2, 2015: 45-53.

Permana, Yogi Setya., Adaba, Pandu Yuhsina. "MENELISIK PERAN TENAGA AHLI ANGGOTA LEGISLATIF", Jurnal Penelitian Politik 8, no. 1, 2011: 83-94.

Pujiraharjo, Harry Susan. "PEGAWAI PEMERINTAH DENGAN PERJANJIAN KERJA (PPPK): SOLUSI DALAM REKRUTMEN PEGAWAI DARI PEGAWAI NON PNS ASN", Jurnal Civil Service 9, no. 2, 2015: 21-30.

Putranto, Agustinus Sulistyo Tri. "PEGAWAI PEMERINTAH DENGAN PERJANJIAN KERJA: PENGERTIAN DAN URGENSINYA", Jurnal Kebijakan dan Manajemen PNS 9, no. 2, 2015: 1-10.

Ramadhani, Dwi Aryanti., Joesoef, Iwan Erar. "PERLINDUNGAN HUKUM PEGAWAI PEMERINTAH DENGAN PERJANJIAN KERJA (PPPK) DALAM KONSEP PERJANJIAN KERJA WAKTU TERTENTU DI INSTITUSI PERGURUAN TINGGI", Jurnal Yuridis 7, no. 1, 2020: 1-26, 23, DOI: 10.35586/jyur.v7i1.1308.

Tobirin. "TANTANGAN DAN PELUANG PENERAPAN MANAJEMEN BERBASIS KINERJA PADA PEGAWAI PEMERINTAH DENGAN PERJANJIAN KERJA DI DAERAH", Jurnal Civil Service 9, no. 2, 2015: 71-79.

Wawanudin., Sudarno, Rohidin. "PELAKSANAAN SISTEM MERIT DALAM UU ASN, WEWENANG KASN DAN ANALISIS PERATURAN PERUNDANG-UNDANGAN YANG BERPENGARUH TERHADAP WEWENANG KASN", Jurnal Mozaik 10, no. 1, 2018: 26-40.

\section{B. Buku}

Hartini, Sri, dkk., Hukum Kepegawaian di Indonesia, Cetakan Ketiga, Jakarta: Sinar Grafika, 2014.

Siswadi, Edi. Birokrasi Masa Depan Menuju Tata Kelola Pemerintahan yang Efektif dan Prima. Bandung: Mutiara Press, 2012.

\section{Peraturan}

Republik Indonesia, Peraturan Pemerintah tentang Manajemen Pegawai Pemerintah dengan Perjanjian Kerja, Peraturan Pemerintah Nomor 49 Tahun 2018. 
Republik Indonesia, Peraturan Pemerintah tentang Pengangkatan Tenaga Honorer Menjadi Calon Pegawai Negeri Sipil, Peraturan Pemerintah Nomor 48 Tahun 2005 sebagaimana telah diubah beberapa kali terakhir dengan Peraturan Pemerintah Nomor 56 Tahun 2012.

Republik Indonesia, Undang-Undang tentang Aparatur Sipil Negara, UU Nomor 5 Tahun 2014, LN Nomor 6 Tahun 2014, TLN Nomor 5494.

Republik Indonesia, Undang-Undang tentang Ketenagakerjaan, UU Nomor 13 Tahun 2003, LN Nomor 39 Tahun 2003, TLN Nomor 4279.

Republik Indonesia, Undang-Undang tentang Perubahan Atas Undang-Undang Nomor 8 Tahun 1974 tentang Pokok-Pokok Kepegawaian, UU Nomor 43 Tahun 1999, LN Nomor 169 Tahun 1999, TLN Nomor 3890. 


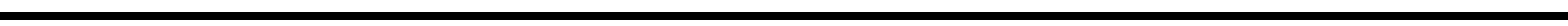

